\title{
Environmental and occupational exposures associated with male infertility
}

\author{
Tihana Marić ${ }^{1,3}$, Aleksandra Fučić ${ }^{2,3}$, and Anna Aghayanian ${ }^{4}$ \\ ${ }^{1}$ University of Zagreb School of Medicine, Department of Medical Biology, Zagreb, Croatia \\ ${ }^{2}$ Institute for Medical Research and Occupational Health, Zagreb, Croatia \\ ${ }^{3}$ Scientific Centre of Excellence for Reproductive and Regenerative Medicine, University of Zagreb School of \\ Medicine, Zagreb, Croatia \\ ${ }^{4}$ Medical Institute Peoples' Friendship University of Russia (RUDN University), Moscow, Russia
}

[Received in November 2020; Similarity Check in November 2020; Accepted in May 2021]

\begin{abstract}
The upsurge in male infertility over the last two decades, possibly due to environmental exposure, has raised significant interest, particularly boosted by reports from fertility clinics, which showed that chronic diseases and hereditary or other medical conditions might only partially explain current incidence of male infertility. Both environmental and occupational settings may have a significant role in exposure to complex mixtures of endocrine disruptors (ED), which play a major role in fertility disorders. The aim of this review is to give an insight into the current knowledge on exposure settings which may be associated with male infertility. Our study relied on a systematic search of PubMed, Scopus, and Web of Science for articles published between January 2000 and September 2020. It showed that some well documented factors associated with male infertility include smoking, and physiological disturbances or chronic diseases such as obesity and diabetes, which in turn, may also reflect lifestyle choices and environmental exposures, especially to EDs such as phthalates, bisphenols, pesticides, and flame retardants. However, the number of studies on the aetiology of male infertility is still too low in comparison with the size of affected population. Occupational health follow-ups and medical surveillance do not collect any data on male infertility, even though ED chemicals are part of many technological processes.
\end{abstract}

KEY WORDS: alcohol; bisphenols; diet; electromagnetic fields; endocrine disruptors; obesity; parabens; phthalates; pesticides; smoking; sperm-

Infertility is defined as inability to conceive a child after one year of unprotected intercourse (1). It affects $10-15 \%$ of all couples and varies between countries and geographic regions. Men and women contribute equally to the problem, and often more than one infertility factor is involved $(2,3)$. Medical diagnosis of male infertility relies on sex hormone status assessment and semen analysis that evaluates sperm count, motility, and morphology, and infertile patients are advised to take assisted reproductive technology (ART) treatment to address the issue. Although semen analysis is performed in clinical and research laboratories across the world on a daily basis, the cause often remains unknown and cannot be explained by hormonal and testicular disorders and genetic factors such as Klinefelter syndrome $(X X Y)$, rearrangements in the $A Z F$ gene, and mutations in other infertility related genes, such as $A R, C F T R, N R 5 A 1$, and $\operatorname{SRY}(4,5)$.

Spermatogenesis is a highly complex cyclic process of haploid spermatozoa maturation from diploid undifferentiated spermatogonia and can therefore respond

Corresponding author: Tihana Marić, University of Zagreb School of Medicine, Šalata 3, Department of Medical Biology, Zagreb, Croatia E-mail: tihana.maric@mef.hr, ORCID: 0000-0002-6238-9811 to everyday stressors - occupational and environmental (6). As industry bloomed exponentially in recent decades (with the exception of 2008) and brought many improvements to everyday life, it also became the source of occupational and environmental exposure to different chemical compounds and their mixtures (Figure 1). Those among them that affect hormonal regulation are usually termed endocrine disrupting chemicals (EDCs). They can be present in pesticides, food contaminants, cosmetic products, water, and air (7).

In males, EDCs affect hypothalamus that stimulates pituitary gland to secrete gonadotropins - luteinising hormone ( $\mathrm{LH})$ and follicle-stimulating hormone (FSH) which regulate spermatogenesis through Leydig cell androgen secretion and Sertoli cell activation (8). Since hormones tightly control male reproductive system, EDCs that act as anti-androgens or mimic oestrogens may interfere with these mechanisms and have a profound impact on healthy sperm production (9). However, data on their impact on human reproductive health are still scarce and mechanisms not completely elucidated, especially as EDCs are usually present in different mixtures. A more straightforward negative correlation has been observed between disrupted spermatogenesis and lifestyle factors

Tihana Marić and Aleksandra Fučić equally contributed to manuscript preparation. 


\section{Occupational exposure}

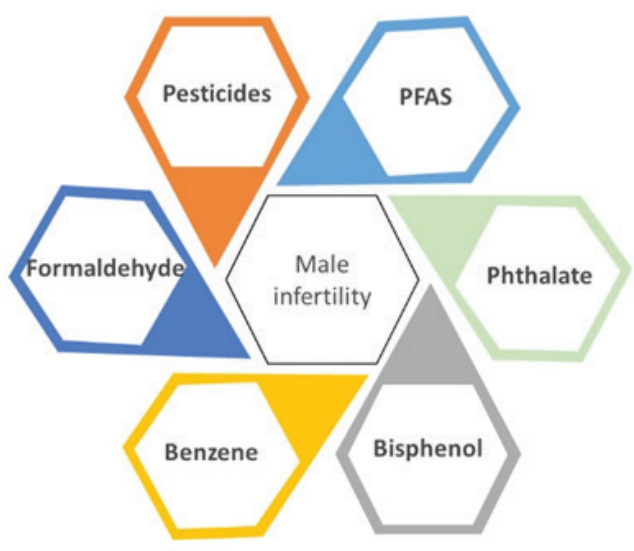

\section{Environmental exposure}

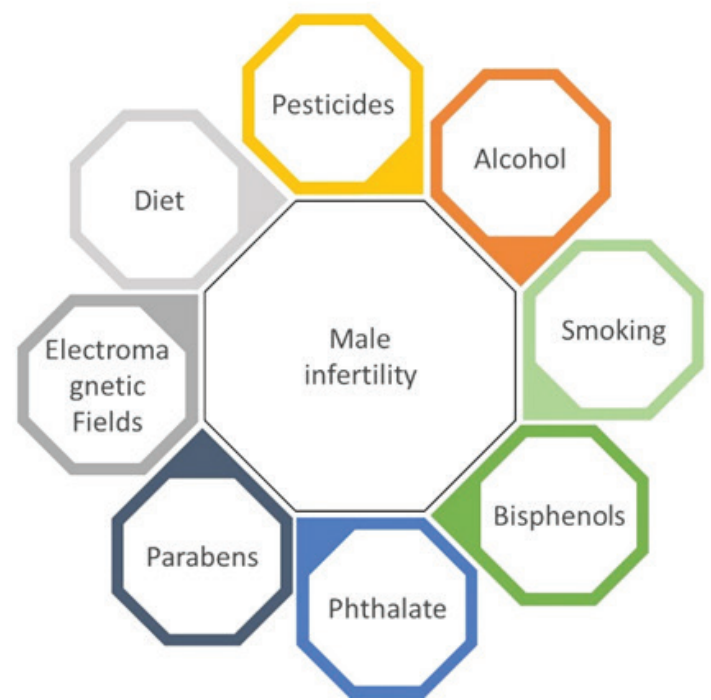

Figure 1 Overview of occupational and environmental stressors associated with male infertility

such as alcohol consumption, cigarette smoking, drug use, and obesity caused by high-energy diet (10). In addition, periodical exposure to excess heat, noise, vibrations, and electromagnetic fields may cause accumulation of DNA damage in sperm and affect fertility (11). Researchers have also suggested a connection between male infertility and air pollution, with still unclear conclusions (12). Seasonal changes and natural disasters could also affect male reproductive status $(13,14)$. All this shows that spermatogenesis and male fertility may depend on many circumstances created over years of exposure to different contaminants from the environment combined with genetic factors.

This review will focus on various occupational and environmental exposures and their effects on human spermatogenesis, sex hormone pathways, and overall male fertility. It will include epidemiological studies trying to find associations between male infertility and ECDs, pesticides, metals, air pollution, lifestyle, heat, noise, and electromagnetic waves but will not include ionising radiation, as, according to the current occupational radiation protection regulations, the existing exposure levels do not represent any fertility risk in men (https://www.iaea.org/ resources/safety-standards).

The review is based on a systematic search of articles published between January 2000 and September 2020 indexed in PubMed, Scopus, and Web of Science regardless of the language. It does not include conference abstracts.

\section{OCCUPATIONAL EXPOSURE}

The association between occupational exposure and infertility is still neglected, and studies are rare and lacking 
systematic approach, even in developed countries. Occupational health protocols for many occupations in which it is known that technological processes may include exposure to EDCs do not include any medical examination or data collection on fertility status (15). A significant input, however, has been given by infertility clinics, which actively try to find the cause of infertility, as this might enhance the efficiency of ART.

Over the last few decades, they have identified several groups of compounds as potentially associated with male infertility, although life habits like smoking and alcohol may significantly mask or interact with the effects of these compounds present in occupational settings.

Studies of occupational exposure to benzene and its mixture with toluene and xylene have shown an association between benzene levels in blood and seminal plasma, significant genome damage, abnormal sperm count, motility, morphology $(16,17)$, disomy $\mathrm{X}$ and $\mathrm{Y}$, and hyperhaploidy, even at low levels ( $\leq 1 \mathrm{ppm})$ (18).

A large Tunisian study (19) with 2122 men who visited infertility clinics and filled a detailed questionnaire showed that occupational exposure to pesticides was associated with a significantly higher risk of asthenozoospermia and necrozoospermia, while exposure to cement correlated with a higher risk of oligozoospermia. However, it found no association between semen impairment and exposure to solvents, excess heat, or mechanical vibrations. In contrast, one study (20) showed an association between male infertility and exposure to solvents and painting materials, lead, work with computers, shift work and work-related stress. A large Canadian national study (21) found a significant decrease in sperm motility in participants occupationally exposed to high levels of solvents (21), as did a recent meta-analysis of 272 exposed and 247 unexposed men (22).

Although the consumer use of formaldehyde at concentrations $\geq 0.1 \%$ has been prohibited in the EU (23) due to its carcinogenicity, it is still omnipresent in the environment and widely used in resin production, construction, wood processing, textiles, hospitals, laboratories, and chemical industry and its sales are expected to reach US\$34.8 billion by 2026 . With this in mind, continuous efforts are made to limit/control its occupational exposure (24). In terms of male infertility, formaldehyde has been shown to significantly lower progressive and total sperm motility in a dose-dependent manner (25).

The major problem with pesticides is that exposure may be both environmental and occupational. It will depend on technology and timing of pesticide application and farming type. Pesticides as a group of chemicals which includes insecticides, herbicides, and fungicides express endocrine effects from xenoestrogens to aromatase inhibitors.

Sperm analysis in groundnut farmers in Myanmar who used chlorpyrifos and carbamates, often above recommended dosages, revealed that $74 \%$ had oligozoospermia in the growing season, which was less pronounced (46\%) in the non-growing season (26). In abamectin-exposed farmworkers, significantly increased abamectin plasma levels were associated with significant genome damage and immaturity of spermatozoa, even though testosterone, LH, and FSH levels were normal (25). Similarly, exposure of farmworkers to organophosphate and carbamate pesticides, which was confirmed by elevated erythrocyte acetylcholinesterase ( $\mathrm{AChE}$ ) and plasma butyrylcholinesterase $(\mathrm{BuChE})$, was associated with lower sperm motility and sperm immaturity without significant deviations from normal serum testosterone, LH, and FSH levels (27).

The use of ethylene glycol-based chemicals is common in many commercial and industrial applications, including solvents, antifreeze, and coolants. One study (28) reported occupational exposure to be associated with low motile sperm count, but the risk diminished after adjustment for confounders. In vitro, ethylene glycol was reported to increase oestradiol levels in H295R cells (29). In rats and mice, ethylene glycol monomethyl ether (EGME) lowered the expression of spermatocyte-specific genes (30) and germ cell lineage (31), respectively. In cynomolgus monkeys, it damaged spermatocytes in the pachytene stage, implicating miR-34b-5p and miR-449a downregulation in the process (32).

An increased risk of infertility has been reported in full-time firefighters (33), as their occupational setting is associated with exposure to a complex mixture of chemicals, including those known to be ED such as flame retardants, polyaromatic hydrocarbons (PAHs), as well as with hyperthermia, stress, and circadian rhythm disturbances due to night-shift work. Of special interest is exposure to per- and poly-fluorinated alkyl substances (PFAS) as the main constituent of aqueous film-forming firefighting foams (34). A human stem-cell-based model of spermatogenesis showed that PFAS lower the expression of markers for spermatogonia and primary spermatocytes without directly affecting germ cell viability, which suggests long-term effects on male fertility through the depletion of the spermatogonial stem cell pool and abnormalities in primary spermatocytes (35).

Exposure to phthalates, more specifically di-n-butyl and di-2-ethylhexyl phthalate, has been shown to lower free testosterone in workers producing unfoamed polyvinyl chloride flooring (36). It is interesting, however, that this study used construction sector workers for control, which may involve a significant bias, as they also may been exposed to phthalates. In a study with polyvinyl chloride (PVC) workers (37), lower sperm motility was associated with higher urinary phthalate metabolites, sperm apoptosis, and ROS generation. In a similar occupational setting, ambient air phthalate levels were positively associated with DNA fragmentation and negatively with sperm motility (38). 
In epoxy resin workers occupationally exposed to bisphenol A exposure was associated with alterations of sperm LINE-1 hydroxymethylation $(39,40)$. In another study, bisphenol A exposure affected gene expression by affecting DNA hydroxymethylation, which partly depends on the trimethylation of histone $\mathrm{H} 3$ in human spermatogenesis (41).

\section{ENVIRONMENTAL EXPOSURE}

Market globalisation and global mobility of goods and people have also globalised exposure through goods, canned or fresh food, and global transport of waste. In addition to common habits such as smoking and drinking, diet is also losing national characteristics, and distribution of potential food contaminants in canned or fresh food has become global. However, infertility issues associated with environmental exposure are still neglected by the media and educational programmes for the general population. In addition, environmental exposure has become so complex that it is almost impossible to reliably assess infertility risk. This is additionally challenging due to inter-individual differences in susceptibility, age, and unknown transplacental exposure with possible lifelong effects.

\section{SMOKING}

A large number of studies have associated smoking with poorer sperm quality (42-52) and suggested that quitting tobacco use and improving general lifestyle would improve male fertility. Sharma et al. (44) conducted a large metaanalysis of the effects of cigarette smoking and reported that moderate and heavy smoking affected sperm count, motility, and morphology. Another study (45) did not find any significant difference in the effects between those who smoked more and less cigarettes per day, which suggests that even mild smoking could impair spermatogenesis. Furthermore, heavy smoking has been reported to induce ferroptosis in seminal plasma (46) and to affect sperm motility (47). Among infertility clinic patients, smokers had lower ejaculate and seminal vesicle volume than nonsmokers but not lower testosterone (48).

One predictor of genome damage through disease, environmental exposure and lifestyle is the aberrant methylation of repetitive elements such as LINE-1 (53). Normal methylation of different genomic elements is also important for fertility. One Chinese cohort study found that hypermethylation of LINE-1 and hypomethylation of the P16 gene were significantly associated with tobacco smoking in men with infertility risk (49).

Higher accumulation of ROS, such as superoxide anion and hydroxyl radicals, in the testes of tobacco smokers causes oxidative stress to which sperm is sensitive, as its plasma membrane is rich in polyunsaturated fatty acids (PUFA) and its cytoplasm deficient in scavenging enzymes
(50). Oxidative stress may also render the acrosome membrane temporarily permeable to calcium ions that trigger premature acrosome reaction (51). Antoniassi et al. (52) have also associated smoking with lower sperm mitochondrial activity and increased pro-inflammatory response in accessory glands and the testes.

The testes are also susceptible to cadmium $(\mathrm{Cd})$ and lead $(\mathrm{Pb})$ from tobacco smoke absorbed by the lungs (54). Both act as metalloestrogens and have been reported to accumulate more in the blood and semen of smokers than non-smokers (55). Higher levels of $\mathrm{Cd}$ and $\mathrm{Pb}$ are associated with impaired spermatogenesis and elevated ROS (55). Moreover, $\mathrm{Cd}$ tends to replace zinc $(\mathrm{Zn})$, which is crucial for normal spermatogenesis (56). In rats, $\mathrm{Cd}$ is implicated in age-dependent dysregulation of hypothalamus-pituitarytesticular axis, which means that $\mathrm{Cd}$ exposure can differently affect spermatogenesis with older age (57). Nicotine and its metabolite cotinine can also disrupt spermatozoa parameters in a dose-dependent manner (58). In an in vitro study (59) nicotine reduced the number of TM3 Leydig cells, most likely through autophagy, and, consequently, testosterone synthesis. In vivo nicotine decreased testosterone levels in serum and impaired the function of other sex hormones (FSH, LH and prolactin) in albino rats (60).

\section{ALCOHOL}

Alcohol consumption is another lifestyle factor associated with male infertility but with inconsistent findings, as reviewed by La Vignera et al. (61). One large cross-sectional study with 8344 European and USA participants (62) reported that men who drank alcohol more frequently had higher serum testosterone levels and that moderate alcohol intake did not significantly correlate with semen quality. However, this study did not exclude confounder effects. The authors concluded that elevated testosterone may be related to changed metabolism in the liver and that moderate drinking may not affect men fertility potential. Hoyer et al. (63) also investigated the relationship between male alcohol consumption and couple fertility in an internet cohort study on Danish and North Americans (63). They found no significant association, except for slightly lower conception rates among couples in which men consumed more alcohol.

One Vietnamese study (64), however, reported a significant correlation between alcohol consumption and impaired sperm DNA integrity, which was, in turn, associated with poorer semen quality in infertile men. Several other studies reported similar findings for drinking and abnormal semen parameters, especially morphology, but in combination with smoking (65-67). Smoking and obesity are confounding factors that often come in combination with moderate to heavy alcohol consumption (59) and make alcohol effects impossible to separate unless 
the confounding factors are excluded. One such study with non-smoking chronic alcoholics (68) reported higher serum FSH and LH and lower testosterone levels and semen quality. Studies on alcohol effects on male infertility should also take into account ethnic differences in response to alcohol and other EDs (69). Even so, current knowledge seems to suggest that male infertility is more likely in heavy drinkers, especially if they are smokers and/or obese.

\section{DIET AND OBESITY}

Diet is another important factor that can affect sperm quality. Overweight and obesity are usually the consequence of nutrient-poor and sugar and saturated fat-rich diet in combination with little to no physical activity. The magnitude of this issue has been clearly illustrated by the Global Burden of Disease Study of 2013 (70) claiming that overweight and obesity causes 3.4 million deaths and its prevalence is in rise in the last few decades.

One study based on a food frequency questionnaire and nutritional indices (71), associated healthy eating in men with better sperm quality. Several other studies (72-74) established an association between Western animal-based, high-energy diet with lower quality of sperm. Meanwhile, Mediterranean diet rich in fruits, vegetables, and whole grains does not necessarily correlate with better sperm quality, as reports are somewhat conflicting (74-77).

Disregarding the type of diet, the Longitudinal Investigation of Fertility and Environment (LIFE) study (78) has associated increased body mass index (BMI) and waist circumference with poorer sperm quality in men with unknown fertility status, whereas physical activity had limited effect.

Because testicular function and spermatogenesis are under tight hormonal control, they are subject to every shift in hormonal balance, which, in turn depends on the regulation of hypothalamus-pituitary-testis (HPT) axis, proven to be affected by overweight and obesity (79). One of the mechanisms by which adipose tissue can downregulate spermatogenesis is aromatase overexpression. Aromatase converts testosterone to oestrogen, and the amount of aromatase is proportional to body fat. In other words, body fat reduces testosterone levels in circulation and the testes. Oestrogen can further affect the HPT axis by negative regulatory feedback that downregulates LH and FSH (80).

Furthermore, testicular function may be affected by other hormones released in response to body fat, such as leptin released by adipocytes. One study with an interesting design comparing two obese male groups, one fertile and one infertile, showed that infertile men had significantly higher BMI and leptin levels than the fertile group (81). In contrast, another study (82) did not find any significant association between leptin and infertility, but this may have to do with the fact that infertile study participants were not exclusively obese men. One study (83) also did not find a correlation between leptin and the usual sperm parameters but did find a negative correlation with testosterone, which may point to its adverse effects on testicular function through testosterone-dependent deregulation of Leydig cell steroidogenesis.

There is also the issue of type 2 diabetes and insulin resistance in obese men. A recent longitudinal study (84) investigated a potential bidirectional association between insulin resistance and testosterone levels and showed that baseline lower testosterone could predict insulin resistance but not vice versa after adjustment for body composition, alcohol intake, smoking, hypertension, and diabetes. Other studies showed that obesity, metabolic syndrome, and type 2 diabetes can lead to lower testosterone levels (85-87).

Obesity can also enhance negative effects of environmental toxicants such as bisphenol A (BPA) on spermatogenesis (88). Even though conflicting results have been reported on the relation between obesity and male infertility, it is certain that obese men are more prone to mechanisms that can disrupt spermatogenesis than men with a normal weight range. Moreover, obesity causes hormonal deregulation and increases the risk of many other diseases that may affect male fertility.

\section{PESTICIDES AND FLAME RETARDANTS}

Bretveld et al. (89) have given us a very useful and comprehensive overview of the mechanisms of pesticideinduced reproductive toxicity in men. A number of studies have established associations between exposure to some pesticides in everyday life and sperm parameters. This particularly concerns pyrethroids, used on massive scales because they are highly toxic to insects and barely toxic to mammals, for which reason the popular belief is that they are safe. However, several studies have reported an association between pyrethroid metabolites in nonoccupationally exposed men and abnormal sperm morphology, lower sperm counts, and testosterone levels $(90,91)$. Several metabolites were also associated with disrupted sperm DNA integrity, and higher rates of sex chromosome aneuploidy (90-94). In contrast, two studies with Japanese student population found no significant association between pyrethroid metabolites and sperm quality or reproductive hormones $(95,96)$.

Another group of pesticides that has been associated with reproductive toxicity in men are the organochlorine ones, massively used in the mid- $20^{\text {th }}$ century, some of which were later banned but are still present in the environment due to their chemical persistency (97). Environmental exposure to organochlorines p,p'-DDE and lindane was reported to be associated with lower sperm motility, higher DNA fragmentation, higher ROS production, and depolarised mitochondria (98). One study (99) reported the association between non-occupational exposure to and p,p'-DDT and lower sperm motility and viability. Another 
(99) associated it with oligozoospermia and asthenozoospermia. Lower sperm count was also associated with higher organochlorine hexachlorocyclohexane $(\mathrm{HCH})$ levels found in semen, especially in azoospermic men with deletions in the $A Z F$ region (100).

Organophosphates are another widely used group of pesticides that degrade faster in the environment and are neurotoxic to humans (101). Several classes of organophosphate pesticides found in urine have been associated with lower sperm concentration, count, and motility. One study (102) reported a positive correlation between urinary organophosphate metabolites and FSH and LH were in men with elevated gonadotropins. Another study (103) reported correlation of different organophosphate metabolites in urine with increased sex chromosome disomy.

As organophosphates are also used as flame retardants or plasticisers, their effects were investigated in a large cohort study (104), which reported no or weak correlation between their urinary levels and sperm parameters. In another study (105), only bis(1,3-dichloro-2-propyl) phosphate showed a stronger association with increased sperm count in men attending infertility clinic, but the authors warned that the associations were inconsistent overall.

\section{BISPHENOLS}

Bisphenol A(BPA) is a precursor in plastic industry that acts as an endocrine disruptor and xenoestrogen, which can be found in plastic water bottles, food containers, can coatings, tooth fillings, cash receipts, and plastic toys (106). BPA binds to oestrogen receptors less efficiently than oestradiol but its circulating concentration can be higher than that of oestradiol. BPA also has an antiandrogen effect, because it binds to androgen receptors and inhibits normal androgen response (107). Because of its detrimental effects on male hormonal pathways, several studies investigated BPA impact on sperm parameters. Li et al. (108) found a dose-dependent correlation between higher urinary BPA levels and lower semen quality. In seminal plasma BPA levels were also negatively associated with sperm concentration, count, and morphology in men attending fertility clinic (109). However, several other studies found no or only weak, clinically insignificant associations (110, 111). One study (112) indicated higher BPA levels in Italian men living in a metropolitan area than in those living in a rural area. Furthermore, there were differences between fertile and infertile men but without BPA presenting risk factor for infertility (112). BPA certainly has an impact on the male reproductive system, but its clinical significance is unclear.

\section{PHTALATES}

Phthalate esters can migrate from plastics (such as polyvinyl chloride plastics, food packaging, and toys) into cosmetics, solvents, and medicine film coatings (113). Data on phthalate exposure effects on male infertility are most often collected at infertility clinics. The disadvantage of such data collection is that it is not always clear whether exposure has been environmental or occupational.

Even so, evidence of the association is rather convincing, such as that between phthalate metabolite levels and decreased sperm quality $(114,115)$. Findings reported for general population are not as consistent. Those reporting phthalate effects on sperm quality but not on reproductive hormone levels suggest that phthalates deteriorate semen quality via ROS production, lipid peroxidation, and mitochondrial dysfunction (116-121). There where hormonal effects were reported, more specifically changes in testosterone to oestradiol ratio, the authors suspected possible effects on aromatase suppression $(122,123)$.

One study investigating the effects of environmental exposure to complex chemical mixtures reported an interesting finding of a synergistic effect of polychlorinated biphenyls and monobutyl phthalate on sperm damage (124).

\section{PARABENS}

Antimicrobial preservatives such as parabens and triclosan are common additives in consumer goods. In the US, 58-99 \% of general population have their detectable concentrations in the urine. As both have endocrine disrupting properties, both have been investigated for adverse effects on male fertility. Hydroxylated paraben metabolites and triclosan have shown significant association with some semen quality parameters $(115,125)$. Additionally, urinary paraben concentrations were reported to be significantly associated with abnormal sperm morphology, lower motility and testosterone levels, and XY18 and chromosome 13 disomy $(126,127)$. Similar to other endocrine disruptors, parabens have also been suggested to play a role in mitochondrial dysfunction (128).

\section{ELECTROMAGNETIC FIELDS}

Environmental exposure to electromagnetic fields from cell phone use, telecommunication towers, and radars has been a source of public controversy for decades. Research of its influence on male fertility has also produced some controversial findings, most likely because studies have greatly differed in design and experimental conditions. One recent study (129) has shown a significant association between living close to a telecommunication tower and lower sperm volume and between carrying mobile phone in trouser pockets and lower sperm motility. Similar results were reported in a meta-analysis of ten in vitro and in vivo 
observational studies (130). One study (131) reported a significant association between phone use duration and lower sperm count and concentration. Some studies explain these effects on sperm quality with disturbances in mitochondrial function caused by extremely low frequency electromagnetic fields and the resulting elevated ROS production $(132,133)$.

The risk of male infertility is of particular concern among adolescents who are using cell phones more than $10 \mathrm{~h}$ a day (134). However, continuous changes in technology and application of cell phones make it extremely difficult to conduct comparable studies on their effects, especially if we take into consideration the effects of many other electronic devices used from early childhood and the specific biological effects of sex and age, all of which create a complex exposure, much similar to exposure to complex chemical mixtures, which is why it is difficult to clearly identify causality between a certain exposure type and its biological effect.

\section{CONCLUSION}

Table 1 summarises our literature review of current occupational and environmental risks for male fertility.
Male infertility is a serious health condition that affects a large number of men especially in developed countries. A large number of chemicals with endocrine disrupting potential are present in occupational and environmental settings, usually in the form of complex mixtures. Phthalates, bisphenols, pesticides, and flame retardants as the main chemical groups associated with male infertility risk stand out, but their combined (omni)presence in food, cosmetics, air, and water, poses a great challenge to researchers to establish clear causality and association between exposure to a specific group and male infertility. Poor sperm quality seems to be accompanied by an imbalance in the levels of reproductive hormones and high levels of endocrine disruptors, DNA damage, and epigenetic and mitochondrial disturbances. However, due to the diversity of investigated populations, differences in epidemiological models, and uneven data collection, some of the results seem to be controversial. Yet, there is enough solid evidence for concern. Occupational and environmental exposures significantly contribute to male infertility, but many more studies with large numbers of participants are needed to obtain a data corpus reliable enough to determine effective preventive and/or protective measures and make

Table 1 Types of biochemical, cytological, genetic, and epigenetic disorders in male infertility after occupational and environmental exposure to stressors

\begin{tabular}{|c|c|c|c|c|}
\hline Disorder & Occupational exposure & References & Environmental exposure & References \\
\hline Hormonal & Testosterone $\downarrow$ & $(24,33,35)$ & $\begin{array}{c}\text { Testosterone } \downarrow \\
\text { Oestradiol } \downarrow \\
\text { Aromatase } \downarrow \\
\text { Gonadotropins } \uparrow \\
\text { Aromatase } \uparrow \\
\text { Leptin } \uparrow\end{array}$ & $\begin{array}{c}(38,39,42,43,46 \\
47,58,115,116 \\
119,120)\end{array}$ \\
\hline Sperm & $\begin{array}{c}\text { Sperm motility } \downarrow \\
\text { Apoptosis } \uparrow \\
\text { ROS generation } \\
\text { Sperm count } \downarrow \\
\text { Asthenozoospermia } \\
\text { Necrozoospermia } \\
\text { Oligozoospermia } \\
\text { Sperm immaturity } \uparrow\end{array}$ & $(14,17-25,34,35)$ & $\begin{array}{c}\text { Sperm count } \downarrow \\
\text { Sperm motility } \downarrow \\
\text { Abnormal morphology } \uparrow \\
\text { Oligozoospermia } \\
\text { Asthenozoospermia } \\
\text { Azoospermia } \\
\text { Apoptosis } \uparrow\end{array}$ & $\begin{array}{c}(6,7,25-28,36,46, \\
47,55,56,58,59, \\
63,64,107,108, \\
117-120,122,124)\end{array}$ \\
\hline Mitochondrial & - & - & $\begin{array}{c}\text { Disturbances in } \\
\text { mitochondria functionality }\end{array}$ & $(121,125,126)$ \\
\hline DNA & $\begin{array}{c}\text { DNA fragmentation } \\
\text { Genome damage } \\
\text { Disomy } \mathrm{X} \uparrow \\
\text { Disomy Y } \uparrow \\
\text { Hyperhaploidy }\end{array}$ & $(14,15,23,35)$ & $\begin{array}{c}\text { XY18 disomy } \\
\text { Disomy of chromosome } 13 \\
\text { Disrupted DNA integrity } \\
\text { Sex chromosome aneuploidy } \\
\text { Deletions in AZF region } \\
\text { Sex chromosome disomy } \\
\text { DNA damage } \\
\text { DNA fragmentation }\end{array}$ & $\begin{array}{c}(11,24,48-50, \\
55,56,58,59, \\
119-121)\end{array}$ \\
\hline
\end{tabular}

Sperm LINE-1 hydroxymethylation

DNA methylation
DNA hydroxymethylation partially dependent on trimethylation of $\mathrm{H} 3$ in human spermatogenesis
Hypermethylation of LINEP16 gene

(36-38) 1 and hypomethylation of 
infertility part of risk assessment in occupational health surveillance programmes.

\section{Conflict of interests}

None to declare.

\section{Acknowledgments}

This publication was financed through the European Regional Development Fund Operational Programme Competitiveness and Cohesion, under grant agreement No. KK.01.1.1.01.0008 Regenerative and Reproductive Medicine - Exploring New Platforms and Potentials.

\section{REFERENCES}

1. Zegers-Hochschild F, Adamson GD, de Mouzon J, Ishihara O, Mansour R, Nygren K, Sullivan E, Vanderpoel S. International Committee for Monitoring Assisted Reproductive Technology (ICMART) and the World Health Organization (WHO) revised glossary of ART terminology, 2009. Fertil Steril 2009;92:1520-4. doi: 10.1016/j. fertnstert.2009.09.009

2. Dominguez AA, Reijo Pera RA. Infertility. In: Maloy S, Hughes K, editors. Brenner's encyclopedia of genetics. $2^{\text {nd }}$ ed. San Diego: Academic Press; 2013. p. 71-4.

3. Agarwal A, Mulgund A, Hamada A, Chyatte MR. A unique view on male infertility around the globe. Reprod Biol Endocrinol 2015;13:37. doi: 10.1186/s12958-015-0032-1

4. Jungwirth A, Giwercman A, Tournaye H, Diemer T, Kopa Z, Dohle G, Krausz C; European Association of Urology Working Group on Male Infertility. European Association of Urology guidelines on Male Infertility: the 2012 update. Eur Urol 2012;62:324-32. doi: 10.1016/j.eururo.2012.04.048

5. Aitken RJ. The male is significantly implicated as the cause of unexplained infertility. Semin Reprod Med 2020;38:3-20. doi: 10.1055/s-0040-1718941

6. Gabrielsen JS, Tanrikut C. Chronic exposures and male fertility: the impacts of environment, diet, and drug use on spermatogenesis. Andrology 2016;4:648-61. doi: 10.1111/ andr. 12198

7. Santi D, Vezzani S, Granata AR, Roli L, De Santis MC, Ongaro C, Donati F, Baraldi E, Trenti T, Setti M, Simoni M. Sperm quality and environment: a retrospective, cohort study in a Northern province of Italy. Environ Res 2016;150:14453. doi: 10.1016/j.envres.2016.05.053

8. Weinbauer GF, Nieschlag E. Gonadotrophin control of testicular germ cell development. Adv Exp Med Biol 1995;377:55-65. doi: 10.1007/978-1-4899-0952-7_4

9. Diamanti-Kandarakis E, Bourguignon J-P, Giudice LC, Hauser R, Prins GS, Soto AM, Zoeller RT, Gore AC. Endocrine-disrupting chemicals: an Endocrine Society scientific statement. Endocr Rev 2009;30:293-342. doi: 10.1210/er.2009-0002

10. Rehman I, Ahmad G, Alshahrani S. Lifestyle, environment, and male reproductive health: A lesson to learn. In: Sikka S, Hellstrom W, editors. Bioenvironmental issues affecting men's reproductive and sexual health. Academic Press, 2017. p. 157-71.
11. Agarwal A, Desai NR, Makker K, Varghese A, Mouradi R, Sabanegh E, Sharma R. Effects of radiofrequency electromagnetic waves (RF-EMW) from cellular phones on human ejaculated semen: an in vitro pilot study. Fertil Sterile 2009;92:1318-25. doi: 10.1016/j.fertnstert.2008.08.022

12. Jurewicz J, Dziewirska E, Radwan M, Hanke W. Air pollution from natural and anthropic sources and male fertility. Reprod Biol Endocrinol 2018;16:109. doi: 10.1186/s12958-0180430-2

13. Chen Z, Godfrey-Bailey L, Schiff I, Hauser R. Impact of seasonal variation, age and smoking status on human semen parameters: The Massachusetts General Hospital experience. J Exp Clin Assist Reprod 2004;1:2. doi: 10.1186/1743-1050$1-2$

14. Lin C-YC. Instability, investment, disasters, and demography: Natural disasters and fertility in Italy (1820-1962) and Japan (1671-1965). Popul Environ 2010;31:255-81. doi: 10.1007/ s11111-010-0103-3

15. Fucic A, Galea KS, Duca RC, El Yamani M, Frery N, Godderis L, Halldorsson TI, Iavicoli I, Ndaw S, Ribeiro E, Viegas S, Moshammer H. Potential health risk of endocrine disruptors in construction sector and plastics industry: a new paradigm in occupational health. Int J Environ Res Public Health 2018;15:1229. doi: 10.3390/ijerph15061229

16. Katukam V, Kulakarni M, Syed R, Alharbi K, Naik J. Effect of benzene exposure on fertility of male workers employed in bulk drug industries. Genet Testing Mol Biomarkers 2012;16:592-7. doi: 10.1089/gtmb.2011.0241

17. Xiao G, Pan C, Cai Y, Lin H, Fu Z. Effect of benzene, toluene, xylene on the semen quality and the function of accessory gonad of exposed workers. Ind Health 2001;39:206-10. doi: 10.2486/indhealth.39.206

18. Xing C, Marchetti F, Li G, Weldon RH, Kurtovich E, Young S, Schmid TE, Zhang L, Rappaport S, Waidyanatha S, Wyrobek AJ, Eskenazi B. Benzene exposure near the U.S. permissible limit is associated with sperm aneuploidy. Environ Health Perspect 2010;118:833-9. doi: 10.1289/ ehp.0901531

19. Daoud S, Sellami A, Bouassida M, Kebaili S, Ammar Keskes L, Rebai T, Chakorun Feki N. Routine assessment of occupational exposure and its relation to semen quality in infertile men: a cross-sectional study. Turk J Med Sci 2017;47:902-7. doi: 10.3906/sag-1605-47

20. El-Helaly M, Awadalla N, Mansour M, El-Biomy Y. Workplace exposures and male infertility - a case-control study. Int J Occup Med Environ Health 2010;23:331-8. doi: 10.2478/v10001-010-0039-y

21. Cherry N, Labrèche F, Collins J, Tulandi T. Occupational exposure to solvents and male infertility. Occup Environ Med 2001;58:635-40. doi: 10.1136/oem.58.10.635

22. Ianos O, Sari-Minodier I, Villes V, Lehucher-Michel MP, Loundou A, Perrin J. Meta-analysis reveals the association between male occupational exposure to solvents and impairment of semen parameters. J Occup Environ Med 2018;60:e533-e42. doi: 10.1097/jom.0000000000001422

23. Commission Regulation (EU) 2018/675 of 2 May 2018 amending the Appendices to Annex XVII to Regulation (EC) No 1907/2006 of the European Parliament and of the Council concerning the Registration, Evaluation, Authorisation and Restriction of Chemicals (REACH) as regards CMR 
substances (Text with EEA relevance) [displayed May 2021] Available at http://data.europa.eu/eli/reg/2018/675/oj

24. Celik-Ozenci C, Tasatargil A, Tekcan M, Sati L, GungorOrdueri N, Isbir M, Usta F, Akar M, Erler F. Effect of abamectin exposure on semen parameters indicative of reduced sperm maturity: a study on farmworkers in Antalya (Turkey). Andrologia 2012;44:388-95. doi: 10.1111/j.1439-0272.2012.01297.x

25. Wang H-x, Li H-c, Lv M-q, Zhou D-x, Bai L-z, Du L-z, Xue X, Lin P, Qiu S-d. Associations between occupation exposure to Formaldehyde and semen quality, a primary study. Sci Rep 2015;5:15874. doi: 10.1038/srep15874

26. Lwin TZ, Than AA, Min AZ, Robson MG, Siriwong W. Effects of pesticide exposure on reproductivity of male groundnut farmers in Kyauk Kan village, Nyaung-U, Mandalay region, Myanmar. Risk Manag Healthc Policy 2018;11:235-41. doi: 10.2147/RMHP.S175230

27. Miranda-Contreras L, Gómez-Pérez R, Rojas G, Cruz I, Berrueta L, Salmen S, Colmenares M, Barreto S, Balza A, Zavala L, Morales Y, Molina Y, Valeri L, Contreras CA, Osuna JA. Occupational exposure to organophosphate and carbamate pesticides affects sperm chromatin integrity and reproductive hormone levels among Venezuelan farm workers. J Occup Health 2013;55:195-203. doi: 10.1539/ joh.12-0144-fs

28. Cherry N, Moore H, McNamee R, Pacey A, Burgess G, Clyma J-A, Dippnall M, Baillie H, Povey A; participating centres of Chaps-UK. Occupation and male infertility: glycol ethers and other exposures. Occup Environ Med 2008; 65:70814. doi: 10.1136/oem.2007.035824

29. Kopp TI, Lundqvist J, Petersen RK, Oskarsson A, Kristiansen $\mathrm{K}$, Nellemann C, Vogel U. In vitro screening of inhibition of PPAR- $\gamma$ activity as a first step in identification of potential breast carcinogens. Hum Exp Toxicol 2015;34:1106-18. doi: 10.1177/0960327115569811

30. Matsuyama T, Yabe K, Kuwata C, Ito K, Ando Y, Iida H, Mori K. Transcriptional profile of ethylene glycol monomethyl ether-induced testicular toxicity in rats. Drug Chem Toxicol 2018;41:105-12. doi: 10.1080/01480545.2017.1320406

31. Wang Z, Li J, Cao D, Liu X, Zhu D. Generation and application of male mice with specific expression of green fluorescent protein in germ cells. Mol Imaging Biol 2016;18:659-66. doi: 10.1007/s11307-016-0947-8

32. Sakurai K, Mikamoto K, Shirai M, Iguchi T, Ito K, Takasaki W, Mori K. MicroRNA profiling in ethylene glycol monomethyl ether-induced monkey testicular toxicity model. J Toxicol Sci 2015;40:375-82. doi: 10.2131/jts.40.375

33. Petersen KU, Hansen J, Ebbehoej NE, Bonde JP. Infertility in a cohort of male Danish firefighters: a register-based study. Am J Epidemiol 2018;188:339-46. doi: 10.1093/aje/kwy235

34. Jian J-M, Chen D, Han F-J, Guo Y, Zeng L, Lu X, Wang F. A short review on human exposure to and tissue distribution of per- and polyfluoroalkyl substances (PFASs). Sci Total Environ 2018;636:1058-69. doi: 10.1016/j. scitotenv.2018.04.380

35. Steves AN, Turry A, Gill B, Clarkson-Townsend D, Bradner JM, Bachli I, Caudle WM, Miller GW, Chan AWS, Easley $4^{\text {th }} \mathrm{CA}$. Per- and polyfluoroalkyl substances impact human spermatogenesis in a stem-cell-derived model. Syst Biol Reprod Med 2018;64:225-39. doi: 10.1080/19396368. 2018.1481465
36. Pan G, Hanaoka T, Yoshimura M, Zhang S, Wang P, Tsukino H, Inoue K, Nakazawa H, Tsugane S, Takahashi K. Decreased serum free testosterone in workers exposed to high levels of di-n-butyl phthalate (DBP) and di-2-ethylhexyl phthalate (DEHP): a cross-sectional study in China. Environ Health Perspect 2006;114:1643-8. doi: 10.1289/ehp.9016

37. Huang LP, Lee CC, Fan JP, Kuo PH, Shih TS, Hsu PC. Urinary metabolites of di(2-ethylhexyl) phthalate relation to sperm motility, reactive oxygen species generation, and apoptosis in polyvinyl chloride workers. Int Arch Occup Environ Health 2014;87:635-46. doi: 10.1007/s00420-0130905-6

38. Huang L-P, Lee C-C, Hsu P-C, Shih T-S. The association between semen quality in workers and the concentration of di(2-ethylhexyl) phthalate in polyvinyl chloride pellet plant air. Fertil Steril 2011;96:90-4. doi: 10.1016/j. fertnstert.2011.04.093

39. Tian Y, Zhou X, Miao M, Li D-K, Wang Z, Li R, Liang H, Yuan W. Association of bisphenol A exposure with LINE-1 hydroxymethylation in human semen. Int J Environ Res Public Health 2018;15:1770. doi: 10.3390/ijerph15081770

40. Miao M, Zhou X, Li Y, Zhang O, Zhou Z, Li T, Yuan W, Li $\mathrm{R}$, Li D-K. LINE-1 hypomethylation in spermatozoa is associated with Bisphenol A exposure. Andrology 2014;2:13844. doi: 10.1111/j.2047-2927.2013.00166.x

41. Zheng H, Zhou X, Li D-K, Yang F, Pan H, Li T, Miao M, Li $\mathrm{R}$, Yuan W. Genome-wide alteration in DNA hydroxymethylation in the sperm from bisphenol A-exposed men. PLoS One 2017;12(6):e0178535-e. doi:10.1371/ journal.pone. 0178535

42. Dupont C, Faure C, Daoud F, Gautier B, Czernichow S, Levy $\mathrm{R}$; ALIFERT collaborative group. Metabolic syndrome and smoking are independent risk factors of male idiopathic infertility. Basic Clin Androl 2019;29:9. doi: 10.1186/s12610019-0090-x

43. Rehman R, Zahid N, Amjad S, Baig M, Gazzaz ZJ. Relationship between smoking habit and sperm parameters among patients attending an infertility clinic. Front Physiol 2019;10:1356. doi: 10.3389/fphys.2019.01356

44. Sharma R, Harlev A, Agarwal A, Esteves SC. Cigarette smoking and semen quality: a new meta-analysis examining the effect of the 2010 World Health Organization laboratory methods for the examination of human semen. Eur Urol 2016;70:635-45. doi: 10.1016/j.eururo.2016.04.010

45. Li Y, Lin H, Ma M, Li L, Cai M, Zhou N, Han X, Bao H, Huang L, Zhu C, Li C, Yang H, Rao Z, Xiang Y, Cui Z, Ao L, Zhou Z, Xiong H, Cao J. Semen quality of 1346 healthy men, results from the Chongqing area of southwest China. Hum Reprod 2009;24:459-69. doi: 10.1093/humrep/den399

46. Ou Z, Wen Q, Deng Y, Yu Y, Chen Z, Sun L. Cigarette smoking is associated with high level of ferroptosis in seminal plasma and affects semen quality. Reprod Biol Endocrinol 2020;18:55. doi: 10.1186/s12958-020-00615-x

47. Shrem G, Brudner Y, Atzmon Y, Michaeli M, Ellenbogen A, Shalom-Paz E. The influence of obesity, smoking, and serum follicular stimulating hormone in azoospermic patients on testicular sperm extraction-intra cytoplasmic sperm injection outcomes: a retrospective cohort study. Medicine (Baltimore) 2019;98(4):e14048. doi: 10.1097/MD.0000000000014048

48. Lotti F, Corona G, Vitale P, Maseroli E, Rossi M, Fino MG, Maggi M. Current smoking is associated with lower seminal 
vesicles and ejaculate volume, despite higher testosterone levels, in male subjects of infertile couples. Hum Reprod 2015;30:590-602. doi: 10.1093/humrep/deu347

49. Zhang W, Li M, Sun F, Xu X, Zhang Z, Liu J, Sun X, Zhang A, Shen Y, Xu J, Miao M, Wu B, Yuan Y, Huang X, Shi H, $\mathrm{Du}$ J. Association of sperm methylation at LINE-1, four candidate genes, and nicotine/alcohol exposure with the risk of infertility. Front Genet 2019;10:1001. doi: 10.3389/ fgene.2019.01001

50. Agarwal A, Saleh RA, Bedaiwy MA. Role of reactive oxygen species in the pathophysiology of human reproduction. Fertil Steril 2003;79:829-43. doi: 10.1016/s0015-0282(02)049488

51. Talbot $\mathrm{P}, \mathrm{Lin} \mathrm{S}$. The effect of cigarette smoke on fertilization and pre-implantation development: assessment using animal models, clinical data, and stem cells. Biol Res 2011;44:18994. doi: 10.4067/S0716-97602011000200011

52. Antoniassi MP, Intasqui P, Camargo M, Zylbersztejn DS, Carvalho VM, Cardozo KH, Bertolla RP. Analysis of the functional aspects and seminal plasma proteomic profile of sperm from smokers. BJU Int 2016;118:814-22. doi: 10.1111/ bju. 13539

53. Marques-Rocha JL, Milagro FI, Mansego ML, Mourão DM, Martínez JA, Bressan J. LINE-1 methylation is positively associated with healthier lifestyle but inversely related to body fat mass in healthy young individuals. Epigenetics 2016;11:49-60. doi: 10.1080/15592294.2015.1135286

54. Jurasović J, Cvitković P, Pizent A, Colak B, Telisman S Semen quality and reproductive endocrine function with regard to blood cadmium in Croatian male subjects. Biometals 2004;17:735-43. doi: 10.1007/s10534-004-16897

55. Kiziler AR, Aydemir B, Onaran I, Alici B, Ozkara H, Gulyasar T, Akyolcu MC. High levels of cadmium and lead in seminal fluid and blood of smoking men are associated with high oxidative stress and damage in infertile subjects. Biol Trace Elem Res 2007;120:82-91. doi: 10.1007/s12011-007-8020-8

56. Ranganathan P, Rao KA, Sudan JJ, Balasundaram S. Cadmium effects on sperm morphology and semenogelin with relates to increased ROS in infertile smokers: An in vitro and in silico approach. Reprod Biol 2018;18:189-97. doi: 10.1016/j.repbio.2018.04.003

57. Lafuente A, Márquez N, Pérez-Lorenzo M, Pazo D, Esquifino AI. Pubertal and postpubertal cadmium exposure differentially affects the hypothalamic-pituitary-testicular axis function in the rat. Food Chem Toxicol 2000;38:913-23. doi: 10.1016/ s0278-6915(00)00077-6

58. Oyeyipo IP, Maartens PJ, du Plessis SS. In vitro effects of nicotine on human spermatozoa. Andrologia 2014;46:887-92. doi: 10.1111/and.12169

59. Zhao X, Xu W, Wu J, Zhang D, Abou-Shakra A, Di L, Wang Z, Wang L, Yang F, Qiao Z. Nicotine induced autophagy of Leydig cells rather than apoptosis is the major reason of the decrease of serum testosterone. Int J Biochem Cell Biol 2018;100:30-41. doi: 10.1016/j.biocel.2018.05.001

60. Oyeyipo IP, Raji Y, Bolarinwa AF. Nicotine alters male reproductive hormones in male albino rats: The role of cessation. J Hum Reprod Sci 2013;6:40-4. doi: 10.4103/09741208.112380

61. La Vignera S, Condorelli RA, Balercia G, Vicari E, Calogero AE. Does alcohol have any effect on male reproductive function? A review of literature. Asian J Androl 2013;15:2215. doi: 10.1038/aja.2012.118

62. Jensen TK, Swan S, Jorgensen N, Toppari J, Redmon B, Punab M, Drobnis EZ, Haugen TB, Zilaitiene B, Sparks AE, Irvine DS, Wang C, Jouannet P, Brazil C, Paasch U, Salzbrunn A, Skakkebaek NE, Andersson AM. Alcohol and male reproductive health: a cross-sectional study of 8344 healthy men from Europe and the USA. Hum Reprod 2014;29:18019. doi: 10.1093/humrep/deu118

63. Hoyer S, Riis AH, Toft G, Wise LA, Hatch EE, Wesselink AK, Rothman KJ, Sørensen HT, Mikkelsen EM. Male alcohol consumption and fecundability. Hum Reprod 2020;35:81625. doi: 10.1093/humrep/dez294

64. Le MT, Nguyen TAT, Nguyen HTT, Nguyen TTT, Nguyen VT, Le DD, Nguyen VQH, Cao NT. Does sperm DNA fragmentation correlate with semen parameters? Reprod Med Biol 2019;18:390-6. doi: 10.1002/rmb2.12297

65. Deshpande PS, Gupta AS. Causes and prevalence of factors causing infertility in a public health facility. J Hum Reprod Sci 2019;12:287-93. doi: 10.4103/jhrs.JHRS_140_18

66. Stutz G, Zamudio J, Santillán ME, Vincenti L, de Cuneo MF, Ruiz RD. The effect of alcohol, tobacco, and aspirin consumption on seminal quality among healthy young men. Arch Environ Health 2004;59:548-52. doi: 10.1080/00039890409603432

67. Condorelli RA, Calogero AE, Vicari E, La Vignera S. Chronic consumption of alcohol and sperm parameters: our experience and the main evidences. Andrologia 2015;47:36879. doi: $10.1111 /$ and. 12284

68. Muthusami KR, Chinnaswamy P. Effect of chronic alcoholism on male fertility hormones and semen quality. Fertil Steril 2005;84:919-24. doi: 10.1016/j. fertnstert.2005.04.025

69. Watts EL, Appleby PN, Albanes D, Black A, Chan JM, Chen C, Cirillo PM, Cohn BA, Cook MB, Donovan JL, Ferrucci L, Garland CF, Giles GG, Goodman PJ, Habel LA, Haiman CA, Holly JMP, Hoover RN, Kaaks R, Knekt P, Kolonel LN, Kubo T, Le Marchand L, Luostarinen T, MacInnis RJ, Mäenpää HO, Männistö S, Metter EJ, Milne RL, Nomura AMY, Oliver SE, Parsons JK, Peeters PH, Platz EA, Riboli E, Ricceri F, Rinaldi S, Rissanen H, Sawada N, Schaefer CA, Schenk JM, Stanczyk FZ, Stampfer M, Stattin P, Stenman U-H, Tjønneland A, Trichopoulou A, Thompson IM, Tsugane S, Vatten L, Whittemore AS, Ziegler RG, Allen NE, Key TJ, Travis RC. Circulating sex hormones in relation to anthropometric, sociodemographic and behavioural factors in an international dataset of 12,300 men. PLoS One 2017;12(12):e0187741. doi: 10.1371/journal.pone.0187741

70. Ng M, Fleming T, Robinson M, Thomson B, Graetz N, Margono C, Mullany EC, Biryukov S, Abbafati C, Abera SF, Abraham JP, Abu-Rmeileh NME, Achoki T, AlBuhairan FS, Alemu ZA, Alfonso R, Ali MK, Ali R, Guzman NA, Ammar W, Anwari P, Banerjee A, Barquera S, Basu S, Bennett DA, Bhutta Z, Blore J, Cabral N, Nonato IC, Chang J-C, Chowdhury R, Courville KJ, Criqui MH, Cundiff DK, Dabhadkar KC, Dandona L, Davis A, Dayama A, Dharmaratne SD, Ding EL, Durrani AM, Esteghamati A, Farzadfar F, Fay DFJ, Feigin VL, Flaxman A, Forouzanfar MH, Goto A, Green MA, Gupta R, Hafezi-Nejad N, Hankey GJ, Harewood HC, Havmoeller R, Hay S, Hernandez L, Husseini A, Idrisov BT, Ikeda N, Islami F, Jahangir E, Jassal SK, Jee SH, Jeffreys M, 
Jonas JB, Kabagambe EK, Khalifa SEAH, Kengne AP, Khader YS, Khang Y-H, Kim D, Kimokoti RW, Kinge JM, Kokubo Y, Kosen S, Kwan G, Lai T, Leinsalu M, Li Y, Liang X, Liu S, Logroscino G, Lotufo PA, Lu Y, Ma J, Mainoo NK, Mensah GA, Merriman TR, Mokdad AH, Moschandreas J, Naghavi M, Naheed A, Nand D, Narayan KMV, Nelson EL, Neuhouser ML, Nisar MI, Ohkubo T, Oti SO, Pedroza A, Prabhakaran D, Roy N, Sampson U, Seo H, Sepanlou SG, Shibuya K, Shiri R, Shiue I, Singh GM, Singh JA, Skirbekk V, Stapelberg NJC, Sturua L, Sykes BL, Tobias M, Tran BX, Trasande L, Toyoshima H, van de Vijver S, Vasankari TJ, Veerman JL, Velasquez-Melendez G, Vlassov VV, Vollset SE, Vos T, Wang C, Wang X, Weiderpass E, Werdecker A, Wright JL, Yang YC, Yatsuya H, Yoon J, Yoon S-J, Zhao Y, Zhou M, Zhu S, Lopez AD, Murray CJL, Gakidou E. Global, regional, and national prevalence of overweight and obesity in children and adults during 1980-2013: a systematic analysis for the Global Burden of Disease Study 2013. Lancet 2014;384:766-81. doi: 10.1016/S0140-6736(14)60460-8

71. Efrat M, Stein A, Pinkas H, Unger R, Birk R. Dietary patterns are positively associated with semen quality. Fertil Steril 2018;109:809-16. doi: 10.1016/j.fertnstert.2018.01.010

72. Danielewicz A, Przybylowicz KE, Przybylowicz M. Dietary patterns and poor semen quality risk in men: a cross-sectional study. Nutrients 2018;10:1162. doi: 10.3390/nu10091162

73. Liu CY, Chou YC, Chao JC, Hsu CY, Cha TL, Tsao CW. The association between dietary patterns and semen quality in a general Asian population of 7282 males. PLoS One 2015;10(7):e0134224. doi: 10.1371/journal.pone.0134224

74. Salas-Huetos A, Babio N, Carrell DT, Bulló M, Salas-Salvadó J. Adherence to the Mediterranean diet is positively associated with sperm motility: A cross-sectional analysis. Sci Rep 2019;9:3389. doi: 10.1038/s41598-019-39826-7

75. Karayiannis D, Kontogianni MD, Mendorou C, Douka L, Mastrominas M, Yiannakouris N. Association between adherence to the Mediterranean diet and semen quality parameters in male partners of couples attempting fertility. Hum Reprod 2016;32:215-22. doi: 10.1093/humrep/dew288

76. Eslamian G, Amirjannati N, Rashidkhani B, Sadeghi M-R, Hekmatdoost A. Intake of food groups and idiopathic asthenozoospermia: a case-control study. Hum Reprod 2012;27:3328-36. doi: 10.1093/humrep/des311

77. La J, Roberts NH, Yafi FA. Diet and men's sexual health. Sex Med Rev 2018;6:54-68. doi: 10.1016/j.sxmr.2017.07.004

78. Eisenberg ML, Kim S, Chen Z, Sundaram R, Schisterman EF, Buck Louis GM. The relationship between male BMI and waist circumference on semen quality: data from the LIFE study. Hum Reprod 2014;29:193-200. doi: 10.1093/ humrep/det 428

79. Cheng CY, Mruk DD. A local autocrine axis in the testes that regulates spermatogenesis. Nat Rev Endocrinol 2010;6:38095. doi: $10.1038 /$ nrendo.2010.71

80. Xu X, Sun M, Ye J, Luo D, Su X, Zheng D, Feng L, Gao L, $\mathrm{Yu}$ C, Guan Q. The effect of aromatase on the reproductive function of obese males. Horm Metab Res 2017;49:572-9. doi: $10.1055 / \mathrm{s}-0043-107835$

81. Hofny ER, Ali ME, Abdel-Hafez HZ, Kamal Eel D, Mohamed EE, Abd El-Azeem HG, Mostafa T. Semen parameters and hormonal profile in obese fertile and infertile males. Fertil Steril 2010;94:581-4. doi: 10.1016/j. fertnstert.2009.03.085
82. Amjad S, Baig M, Zahid N, Tariq S, Rehman R. Association between leptin, obesity, hormonal interplay and male infertility. Andrologia 2019;51(1):e13147. doi: 10.1111/ and.13147

83. Zorn B, Osredkar J, Meden-Vrtovec H, Majdic G. Leptin levels in infertile male patients are correlated with inhibin $\mathrm{B}$, testosterone and SHBG but not with sperm characteristics. Int J Androl 2007;30:439-44. doi: 10.1111/j.1365-2605.2006.00728.x

84. Ottarsdottir K, Nilsson AG, Hellgren M, Lindblad U, Daka B. The association between serum testosterone and insulin resistance: a longitudinal study. Endocr Connect 2018;7:1491500. doi: 10.1530/EC-18-0480

85. Haring R, Ittermann T, Völzke H, Krebs A, Zygmunt M, Felix SB, Grabe HJ, Nauck M, Wallaschofski H. Prevalence, incidence and risk factors of testosterone deficiency in a population-based cohort of men: results from the study of health in Pomerania. Aging Male 2010;13:247-57. doi: $10.3109 / 13685538.2010 .487553$

86. Wang C, Jackson G, Jones TH, Matsumoto AM, Nehra A, Perelman MA, Swerdloff RS, Traish A, Zitzmann M, Cunningham G. Low testosterone associated with obesity and the metabolic syndrome contributes to sexual dysfunction and cardiovascular disease risk in men with type 2 diabetes. Diabetes Care 2011;34:1669-75. doi: 10.2337/dc10-2339

87. Allen NE, Appleby PN, Davey GK, Key TJ. Lifestyle and nutritional determinants of bioavailable androgens and related hormones in British men. Cancer Causes Control 2002;13:353-63. doi: 10.1023/a:1015238102830

88. Hu W, Dong T, Wang L, Guan Q, Song L, Chen D, Zhou Z, Chen M, Xia Y, Wang X. Obesity aggravates toxic effect of BPA on spermatogenesis. Environ Int 2017;105:56-65. doi: 10.1016/j.envint.2017.04.014

89. Bretveld R, Brouwers M, Ebisch I, Roeleveld N. Influence of pesticides on male fertility. Scand J Work Environ Health 2007;33:13-28. doi: 10.5271/sjweh.1060

90. Radwan M, Jurewicz J, Wielgomas B, Sobala W, Piskunowicz M, Radwan P, Hanke W. Semen quality and the level of reproductive hormones after environmental exposure to pyrethroids. J Occup Environ Med 2014;56:1113-9. doi: 10.1097/JOM.0000000000000297

91. Hu Y, Zhang Y, Vinturache A, Wang Y, Shi R, Chen L, Qin K, Tian Y, Gao Y. Effects of environmental pyrethroids exposure on semen quality in reproductive-age men in Shanghai, China. Chemosphere 2020;245:125580. doi: 10.1016/j.chemosphere.2019.125580

92. Meeker JD, Barr DB, Hauser R. Human semen quality and sperm DNA damage in relation to urinary metabolites of pyrethroid insecticides. Hum Reprod 2008;23:1932-40. doi: 10.1093/humrep/den242

93. Ji G, Xia Y, Gu A, Shi X, Long Y, Song L, Wang S, Wang X. Effects of non-occupational environmental exposure to pyrethroids on semen quality and sperm DNA integrity in Chinese men. Reprod Toxicol 2011;31:171-6. doi: 10.1016/j. reprotox.2010.10.005

94. Young HA, Meeker JD, Martenies SE, Figueroa ZI, Barr DB, Perry MJ. Environmental exposure to pyrethroids and sperm sex chromosome disomy: a cross-sectional study. Environ Health 2013;12:111. doi: 10.1186/1476-069X-12-111

95. Imai K, Yoshinaga J, Yoshikane M, Shiraishi H, Mieno MN, Yoshiike M, Nozawa S, Iwamoto T. Pyrethroid insecticide 
exposure and semen quality of young Japanese men. Reprod Toxicol 2014;43:38-44. doi: 10.1016/j.reprotox.2013.10.010

96. Yoshinaga J, Imai K, Shiraishi H, Nozawa S, Yoshiike M, Mieno MN, Andersson A-M, Iwamoto T. Pyrethroid insecticide exposure and reproductive hormone levels in healthy Japanese male subjects. Andrology 2014;2:416-20. doi: 10.1111/j.2047-2927.2014.00202.x

97. Aktar MW, Sengupta D, Chowdhury A. Impact of pesticides use in agriculture: their benefits and hazards. Interdiscip Toxicol 2009;2:1-12. doi: 10.2478/v10102-009-0001-7

98. Pant N, Shukla M, Upadhyay AD, Chaturvedi PK, Saxena DK, Gupta YK. Association between environmental exposure to $\mathrm{p}, \mathrm{p}$ '-DDE and lindane and semen quality. Environ Sci Pollut Res Int 2014;21:11009-16. doi: 10.1007/s11356-0142965-x

99. Aneck-Hahn NH, Schulenburg GW, Bornman MS, Farias P, de Jager C. Impaired semen quality associated with environmental DDT exposure in young men living in a malaria area in the Limpopo Province, South Africa. J Androl 2007;28:423-34. doi: 10.2164/jandrol.106.001701

100. Khan FH, Ganesan P, Kumar S. Y Chromosome microdeletion and altered sperm quality in human males with high concentration of seminal hexachlorocyclohexane $(\mathrm{HCH})$. Chemosphere 2010;80:972-7. doi: 10.1016/j. chemosphere.2010.05.047

101. Suratman S, Edwards JW, Babina K. Organophosphate pesticides exposure among farmworkers: pathways and risk of adverse health effects. Rev Environ Health 2015;30:65-79. doi: 10.1515/reveh-2014-0072

102. Melgarejo M, Mendiola J, Koch HM, Monino-Garcia M, Noguera-Velasco JA, Torres-Cantero AM. Associations between urinary organophosphate pesticide metabolite levels and reproductive parameters in men from an infertility clinic. Environ Res 2015;137:292-8. doi: 10.1016/j. envres.2015.01.004

103. Figueroa ZI, Young HA, Meeker JD, Martenies SE, Barr DB, Gray G, Perry MJ. Dialkyl phosphate urinary metabolites and chromosomal abnormalities in human sperm. Environ Res 2015;143:256-65. doi: 10.1016/j.envres.2015.10.021

104. Messerlian C, Williams PL, Ford JB, Chavarro JE, MínguezAlarcón L, Dadd R, Braun JM, Gaskins AJ, Meeker JD, James-Todd T, Chiu Y-H, Nassan FL, Souter I, Petrozza J, Keller M, Toth TL, Calafat AM, Hauser R; EARTH Study Team. The Environment and Reproductive Health (EARTH) Study: a prospective preconception cohort. Hum Reprod Open 2018;2018(2):hoy001. doi: 10.1093/hropen/hoy001

105. Ingle ME, Mínguez-Alarcón L, Carignan CC, Butt CM, Stapleton HM, Williams PL, Ford JB, Hauser R, Meeker JD; EARTH Study Team. The association between urinary concentrations of phosphorous-containing flame retardant metabolites and semen parameters among men from a fertility clinic. Int J Hyg Environ Health 2018;221:809-15. doi: 10.1016/j.ijheh.2018.05.001

106. Geens T, Aerts D, Berthot C, Bourguignon JP, Goeyens L, Lecomte P, Maghuin-Rogister G, Pironnet A-M, Pussemier L, Scippo M-L, Van Loco J, Covaci A. A review of dietary and non-dietary exposure to bisphenol-A. Food Chem Toxicol 2012;50:3725-40. doi: 10.1016/j.fct.2012.07.059

107. Nagel SC, Bromfield JJ. Bisphenol a: a model endocrine disrupting chemical with a new potential mechanism of action. Endocrinology 2013;154:1962-4. doi: 10.1210/ en.2013-1370

108. Li DK, Zhou Z, Miao M, He Y, Wang J, Ferber J, Herrinton LJ, Gao ES, Yuan W. Urine bisphenol-A (BPA) level in relation to semen quality. Fertil Steril 2011;95:625-30.e1-4. doi: $10.1016 /$ j.fertnstert.2010.09.026

109. Vitku J, Heracek J, Sosvorova L, Hampl R, Chlupacova T, Hill M, Sobotka V, Bicikova M, Starka L. Associations of bisphenol A and polychlorinated biphenyls with spermatogenesis and steroidogenesis in two biological fluids from men attending an infertility clinic. Environ Int 2016;8990:166-73. doi: 10.1016/j.envint.2016.01.021

110. Goldstone AE, Chen Z, Perry MJ, Kannan K, Louis GMB. Urinary bisphenol A and semen quality, the LIFE Study. Reprod Toxicol 2015;51:7-13. doi: 10.1016/j. reprotox.2014.11.003

111. Mendiola J, Jørgensen N, Andersson A-M, Calafat AM, Ye X, Redmon JB, Drobnis EZ, Wang C, Sparks A, Thurston SW, Liu F, Swan SH. Are environmental levels of bisphenol A associated with reproductive function in fertile men? Environ Health Perspect 2010;118:1286-91. doi: 10.1289/ ehp. 1002037

112. La Rocca C, Tait S, Guerranti C, Busani L, Ciardo F, Bergamasco B, Perra G, Mancini FR, Marci R, Bordi G, Caserta D, Focardi S, Moscarini M, Mantovani A. Exposure to endocrine disruptors and nuclear receptors gene expression in infertile and fertile men from Italian areas with different environmental features. Int J Environ Res Public Health 2015;12:12426-45. doi: 10.3390/ijerph121012426

113. Pallotti F, Pelloni M, Gianfrilli D, Lenzi A, Lombardo F, Paoli D. Mechanisms of testicular disruption from exposure to bisphenol A and phtalates. J Clin Med 2020;9:471. doi: $10.3390 / \mathrm{jcm} 9020471$

114. Wang B, Qin X, Xiao N, Yao Y, Duan Y, Cui X, Zhang S, Luo H, Sun H. Phthalate exposure and semen quality in infertile male population from Tianjin, China: Associations and potential mediation by reproductive hormones. Sci Total Environ 2020;744:140673. doi: 10.1016/j. scitotenv.2020.140673

115. Smarr MM, Kannan K, Sun L, Honda M, Wang W, Karthikraj R, Chen Z, Weck J, Buck Louis GM. Preconception seminal plasma concentrations of endocrine disrupting chemicals in relation to semen quality parameters among male partners planning for pregnancy. Environ Res 2018;167:78-86. doi: 10.1016/j.envres.2018.07.004

116. Joensen UN, Frederiksen H, Blomberg Jensen M, Lauritsen MP, Olesen IA, Lassen TH, Andersson A-M, Jørgensen N. Phthalate excretion pattern and testicular function: a study of 881 healthy Danish men. Environ Health Perspect 2012;120:1397-403. doi: 10.1289/ehp.1205113

117. Axelsson J, Rylander L, Rignell-Hydbom A, Jönsson BAG, Lindh $\mathrm{CH}$, Giwercman A. Phthalate exposure and reproductive parameters in young men from the general Swedish population. Environ Int 2015;85:54-60. doi: 10.1016/j. envint.2015.07.005

118. Chen Q, Yang H, Zhou N, Sun L, Bao H, Tan L, Chen H, Ling X, Zhang G, Huang L, Li L, Ma M, Yang H, Wang X, Zou P, Peng K, Liu T, Shi X, Feng D, Zhou Z, Ao L, Cui Z, Cao J. Phthalate exposure, even below US EPA reference doses, was associated with semen quality and reproductive hormones: Prospective MARHCS study in general 
population. Environ Int 2017;104:58-68. doi: 10.1016/j. envint.2017.04.005

119. Specht IO, Toft G, Hougaard KS, Lindh CH, Lenters V, Jönsson BA, Heederik D, Giwercman A, Bonde JPE. Associations between serum phthalates and biomarkers of reproductive function in 589 adult men. Environ Int 2014;66:146-56. doi: 10.1016/j.envint.2014.02.002

120. Pant N, Shukla M, Patel D, Shukla Y, Mathur N, Gupta Y, Saxena DK. Correlation of phthalate exposure with semen quality. Toxicol Appl Pharmacol 2008;231:112-6. doi: 10.1016/j.taap.2008.04.001

121. Li S, Dai J, Zhang L, Zhang J, Zhang Z, Chen B. An association of elevated serum prolactin with phthalate exposure in adult men. Biomed Environ Sci 2011;24:31-9. doi: 10.3967/0895-3988.2011.01.004

122. Meeker JD, Calafat AM, Hauser R. Urinary metabolites of di(2-ethylhexyl) phthalate are associated with decreased steroid hormone levels in adult men. J Androl 2009;30:28797. doi: 10.2164/jandrol.108.006403

123. Mendiola J, Meeker JD, Jørgensen N, Andersson A-M, Liu F, Calafat AM, Redmon JB, Drobnis EZ, Sparks AE, Wang C, Hauser R, Swan SH. Urinary concentrations of di(2ethylhexyl) phthalate metabolites and serum reproductive hormones: pooled analysis of fertile and infertile men. J Androl 2012;33:488-98. doi: 10.2164/jandrol.111.013557

124. Hauser R, Williams P, Altshul L, Calafat AM. Evidence of interaction between polychlorinated biphenyls and phthalates in relation to human sperm motility. Environ Health Perspect 2005;113:425-30. doi: 10.1289/ehp.7305

125. Ye X, Bishop AM, Reidy JA, Needham LL, Calafat AM. Parabens as urinary biomarkers of exposure in humans. Environ Health Perspect 2006;114:1843-6. doi: 10.1289/ ehp. 9413

126. Jurewicz J, Radwan M, Wielgomas B, Dziewirska E, Karwacka A, Klimowska A, Kałużny P, Radwan P, Bochenek M, Hanke W. Human semen quality, sperm DNA damage, and the level of reproductive hormones in relation to urinary concentrations of parabens. J Occup Environ Med 2017;59:1034-40. doi: 10.1097/jom.0000000000001106

127. Jurewicz J, Radwan M, Wielgomas B, Klimowska A, Kałużny P, Radwan P, Jakubowski L, Hanke W. Environmental exposure to parabens and sperm chromosome disomy. Int J Environ Health Res 2017;27:332-43. doi: 10.1080/09603123.2017.1339784

128. Tavares RS, Martins FC, Oliveira PJ, Ramalho-Santos J, Peixoto FP. Parabens in male infertility - Is there a mitochondrial connection? Reprod Toxicol 2009;27:1-7. doi: 10.1016/j.reprotox.2008.10.002

129. Al-Bayyari N. The effect of cell phone usage on semen quality and fertility among Jordanian males. Middle East Fertil Soc J 2017;22:178-82. doi: 10.1016/j.mefs.2017.03.006

130. Adams JA, Galloway TS, Mondal D, Esteves SC, Mathews F. Effect of mobile telephones on sperm quality: a systematic review and meta-analysis. Environ Int 2014;70:106-12. doi: 10.1016/j.envint.2014.04.015

131. Zhang G, Yan H, Chen Q, Liu K, Ling X, Sun L, Zhou N, Wang Z, Zou P, Wang X, Tan L, Cui Z, Zhou Z, Liu J, Ao L, Cao J. Effects of cell phone use on semen parameters: Results from the MARHCS cohort study in Chongqing, China. Environ Int 2016;91:116-21. doi: 10.1016/j. envint.2016.02.028

132. Santini SJ, Cordone V, Falone S, Mijit M, Tatone C, Amicarelli F, Di Emidio G. Role of mitochondria in the oxidative stress induced by electromagnetic fields: Focus on reproductive systems. Oxid Med Cell Long 2018;2018:5076271. doi: 10.1155/2018/5076271

133. Houston BJ, Nixon B, King BV, Iuliis GND, Aitken RJ. The effects of radiofrequency electromagnetic radiation on sperm function. Reproduction 2016;152:R263-76. doi: 10.1530/ rep-16-0126

134. Redmayne M, Smith E, Abramson MJ. Adolescent in-school cellphone habits: a census of rules, survey of their effectiveness, and fertility implications. Reprod Toxicol 2011;32:354-9. doi: 10.1016/j.reprotox.2011.08.006

\section{Okolišna i profesionalna izloženost povezana s muškom neplodnošću}

Porast slučajeva muške neplodnosti tijekom posljednja dva desetljeća, vjerojatno i zbog izloženosti okolišnim čimbenicima, izazvao je značajan interes. Izvješća klinika za neplodnost pokazala su da kronične bolesti i nasljedni čimbenici ili neke zdravstvene smetnje mogu samo djelomično objasniti trenutačnu incidenciju muške neplodnosti. Životni okoliš i radna okolina mogu imati značajnu ulogu u izlaganju složenim smjesama spojeva s endokrinim djelovanjem (ED), koji su povezani s raznim poremećajima plodnosti. Cilj je ovoga preglednog rada dati uvid u trenutačno znanje o tipovima izloženosti koji mogu biti povezani s muškom neplodnošću. Naše se istraživanje oslanjalo na sustavnu pretragu PubMeda, Scopusa i Web of Sciencea za članke objavljene od siječnja 2000. do rujna 2020. Rezultati su pokazali da je za neke čimbenike dobro dokumentirana povezanost s muškom neplodnošću, što uključuje pušenje, neke fiziološke poremećaje te kronične bolesti poput pretilosti i dijabetesa, koji sami po sebi mogu odražavati životne navike i izloženost okolišu, posebice spojevima s ED-om poput ftalata, bisfenola, pesticida i protupožarnih zaštita. Međutim, broj studija o etiologiji muške neplodnosti još je uvijek premalen u usporedbi s veličinom zahvaćene populacije. Medicina rada tijekom sistematskih pregleda ne prikuplja podatke o muškoj neplodnosti premda su spojevi s ED-om prisutni u mnogim tehnološkim procesima.

KLJUČNE RIJEČI: alkohol; bisfenoli; elektromagnetsko zračenje; endokrini poremećaji; ftalati; parabeni; pesticidi; prehrana; pretilost; pušenje; sperma 